\title{
Risk of Obesity towards teenagers
}

\author{
Uma Sunkara ${ }^{1 *}$ and Latha Uppala ${ }^{2}$ \\ ${ }^{1}$ Department of Organic chemistry, Sir C R Reddy Autonomous College, India \\ ${ }^{2}$ Department of Pharmaceutics, SSJ College of pharmacy, India
}

Received: November 4, 2015; Accepted: November 18, 2015; Published: December 22, 2015

*Corresponding author: Uma Sunkara, M.Sc., Department of Organic chemistry, Sir C R Reddy Autonomous College, India, Tel: +91-897-7961818; Email: sumauma212@gmail.com

Obesity is an incident where surplus body fat has accumulated to the person that it valor have a depressing effect on the health, as much as on the mental health. Obesity is a significance of change in extreme nutritional system, lack of physical activity, and hereditary proclivity. A few cases are for most part caused by genes, endocrine disorders, medications, or mental- illness. populace with usual weight, fat hankie contains fat cells, but in obese populace, fat hankie is encumbered with macrophages, cells that gulp down pathogens and other foreign materials and discharge provocative hormones such as TNF- $\alpha$ and interleukin- 6 that frequently activate the immune system at a squat point, therefore causative to a unrelieved provocative position

The menace for gloominess increases in teenagers, with the incidence of Major depressive disorder (MDD) predictable to be $2 \%$ in brood compared with $4 \%$ to $8 \%$ in teenagers. The increasing occurrence of MDD throughout youth ranges from $15 \%$ to $20 \%$, a rate which is equivalent to the life span dominance of MDD in adults. Teenage girls are more probable to expand gloominess all through adolescence than teenage boys. Sexual characteristics differences materialize during near the beginning youth and bear throughout later life

Dejection includes depressed mood, anhedonia, fatigue, feelings of shame or irrelevance, thoughts of death, changes in sleep and craving or psychomotor activity. Troubles with sleep, craving, or psychomotor activity can take place in moreover route (i.e. a person may understand insomnia or hypersomnia; anorexia or increased craving; psychomotor retardation or demonstration).

In teenagers, disposition may be bristly in its place of dejected. Depressed teenagers articulate their depression by being moody, apathetic, aggressive, or by preference fight, or having irritated outbursts. They too articulate anhedonia as being uninterested; they might suffer apologetic for themselves, stumble on others hardhearted, and may perhaps feel that they encompass dissatisfied their parents or teachers.

Several factors that situate teenagers at an improved risk for melancholy embrace peer problems, pessimistic ways of interpreting proceedings, and reduced coping skills while anxious

Compared in the midst of regular weight adolescents, obese adolescents contain a privileged regularity of educate and psychological health tribulations, together with deprived academic concert and confidence, anxiety, depressive disorders, and a greater quantity of reported suicide attempts. spitefulness of this as well as the hurriedly escalating prevalence and unpleasant physical condition outcomes coupled amid overweight and mental health problems, awfully a small amount of intrusion studies have been conducted with teenagers to develop together their strong lifestyles and cerebral health outcome

\section{Conclusion}

The authentication for the straight contributory conduit beginning obesity to dejection is not noteworthy. Obesity may not unswervingly reason depression in adolescents, excluding various other pathways and experiences may possibly lead to dejection ultimately moreover, traumatic life proceedings such as peer maltreatment and weight-based repartee valor biologically impinge on adolescence to dejection and may be a issue that lead to dejection in obese adolescence. The consequence of recognizing these pathways along with factors are to be familiar while to obstruct to avoid depression in obese teenagers.

\section{References}

1. Choban PS, Onyejekwe J, Burge JC, Flancbaum L. A health status assessment of the impact of weight loss following Roux-en-Y gastric bypass for clinically severe obesity. J Am Coll Surg. 1999;188(5):491497.

2. Rodin J, Silberstein L, Striegel MR. Women and weight: a normative discontent. Nebraska Symposium on Motivation. 1984;32:267-307.

3. Sarwer DB, Thompson JK. Obesity and body image disturbance. In Handbook of Obesity Treatment. Wadden TA, Stunkard AJ, Eds. New York, Guilford Press. 2002;447-464.

4. Matz PE, Foster GD, Faith MS, Wadden TA. Correlates of body image dissatisfaction among overweight women seeking weight loss. J Consult Clin Psychol.2002;70(4):1040-1044.

5. Thompson JK, Stice E. Thin-ideal internalization: mounting evidence for a new risk factor for body-image disturbance and eating pathology. Curr Dir Psychol Sci. 2001;10(5):181-183. doi:10.1111/1467-8721.00144.

6. Rodin J. Determinants of body fat and its implications for health. Ann Behav Med. 1992;14(4):275-281. 
7. Istvan J, Zavela K, Weidner G. Body weight and psychological distress in NHANES I. Int J Obes. 1992;16(1):999-1003.

8. Fontaine KR, Barofsky I, Cheskin LJ. Predictors of quality of life for obese persons. J Nervous Mental Disease. 1997;185:120-122.

9. Kolotkin RL, Meter K, Williams GR. Quality of life and obesity. Obesity
Revs. 2001;2(4):219-229. DOI:10.1046/j.1467-789X.2001.00040.x.

10. Deina Nemiary, Ruth Shim, Gail Mattox, Kisha Holden. The Relationship Between Obesity and Depression Among Adolescents. Psychiatr Ann. 2012;42(8): 305-308. doi:10.3928/00485713-20120806-09. 